\title{
The role of financial technology on development of MSMEs
}

\author{
Ica Rika Candraningrat ${ }^{a *}$, Nyoman Abundantia, Ni Wayan Mujiatia ${ }^{a}$ Ray Erlangga ${ }^{a}$ and I Made \\ Gilang Jhuniantara ${ }^{a}$
}

${ }^{a}$ Faculty of Economics and Business, Udayana University, Indonesia

\begin{tabular}{l}
\hline C H R O N I C L E \\
\hline Article history: \\
Received: April 28, 2020 \\
Received in revised format: \\
July 30 2020 \\
Accepted: September 6, 2020 \\
Available online: \\
September 14, 2020 \\
\hline Keywords: \\
Financial Technology (Fintech) \\
MSMEs \\
Accessibility \\
Assistance
\end{tabular}

\section{Introduction}

Micro, Small and Medium Enterprises (MSMEs) play an important role in increasing economic growth in Indonesia, it is proven that the MSME sector has been able to survive in the midst of the crisis that hit Indonesia in 1997, and even today (Khouroh et al., 2020; Sihotang et al., 2020). Kustina et al. (2018) believe that in 2011 MSMEs contributed 56\% of the total gross domestic product (GDP) in Indonesia. However, in carrying out its role, MSMEs also face obstacles and constraints. One of the obstacles faced by MSMEs is capital. Capital is one of the problems that becomes the main focus since the number of MSMEs that have not accessed formal capital is still very low (Lussak et al., 2020). The total micro, small and medium business units (MSMEs) in Indonesia are 59.2 million business units, of which 58.52 million business units or $98.72 \%$ are dominated by micro businesses. But as much as $80.9 \%$ of the total micro businesses in Indonesia do not yet have access to bank financing (Ministry of Cooperatives and Small and Medium Enterprises of Indonesia, 2017). As an alternative in increasing economic growth, MSMEs are still hampered by a number of problems. Internal factors that hinder the growth of MSMEs are the weak aspects of capital, production, product marketing, and human resources. Capital is usually only obtained from individual money

* Corresponding author.

E-mail address: candraningrat@unud.ac.id (I. R. Candraningrat)

(C) 2021 by the authors; licensee Growing Science, Canada doi: $10.5267 /$ j.ac.2020.9.014 
owned by the owner, while the production and marketing that is done is only limited to the knowledge they have. Marketing is usually only performed by word of mouth so that its development is not too rapid. External factors inhibiting the growth of MSMEs are the development and fostering of MSMEs and the limited access of people to financial institutions (Irmawati et al., 2013). Limited public access to financial institutions has an impact on the capital of MSME where MSME entrepreneurs find it difficult to get capital from these financial institutions. Facilities and knowledge to run MSMEs can be found in various facilities. Utilization of technology is a challenge for MSMEs to be able to survive in the current era. The main function of the use of technology is to be able to facilitate each transaction made. Unfortunately, in Indonesia, this facility is underused by businesses and their customers. A study of the problems of MSMEs stated that the problem of the use and utilization of technology is still a major problem for MSMEs (Maier et al., 2016). The technology that is often used for today's transaction processing needs is financial technology. Technology or financial technology services is a form that can be an alternative for financial institutions and their users to provide and get services. Fintech can act as an introduction to services to users who were not previously reached by traditional institutions or services that already exist. Utilization of technology is a challenge for MSMEs to be able to survive in the current era. This technology or service is a form that can be an alternative for financial institutions and their users in providing and obtaining services. Fintech can act as an introduction to services to users who were not previously reached by traditional institutions or services that already exist. Some forms of fintech breakthrough can change traditional financial products into many variations. For example, in savings and loan solutions, with MSMEs Fintechs can access financing facilities that were previously constrained by bureaucracy in other financial institutions, such as banks. Fintech simplifies the financing process since it can provide loans without collateral. Lenders can come from people who have more money in any amount, and borrowers can come from any community and in any amount. This eliminates some of the conditions and bureaucracy that originally existed in the previous institutions while still being overseen by the government (Yacob et al., 2021).

In Denpasar, there are various types of MSMEs that are scattered throughout the region and are one of the regions in Indonesia where the development of MSMEs is quite fast. In 2012, the number of MSMEs in Denpasar reached 566 units, and in 2017 the number of MSMEs increased to 1,500 units and in 2018 the number showed 1,800 units (Integrated Business Service Center (PLUT) -Denpasar 2018). The rapid growth of the number of MSMEs is due to the support of the Denpasar city government in spurring the development of people's purchasing power, both from local tourists and foreign tourists, which has an impact on increasing the growth of MSMEs in Denpasar City. The Government of Denpasar City, through the UMKM service, tries to strive for things that can realize the absorption of financial inclusion through financial technology, which is running well, namely by providing assistance to MSME players as well as easy access or accessibility to financial technology facilities itself. This is accomplished in order to encourage MSME players to develop capital from these MSMEs and be more advanced.

\section{Literature review}

\subsection{MSMEs}

Based on the Law of the Republic of Indonesia Number 20 of 2008 concerning Micro, Small and Medium Enterprises, Micro Business is defined as productive businesses owned by individuals and / or individual business entities that meet the criteria of micro businesses as regulated in the Act. Small business is a productive economic business that stands alone, which is carried out by individuals or business entities that are not subsidiaries or branch companies that are owned, controlled, or become part, either directly or indirectly, from micro businesses or large businesses that fulfill small business criteria as referred to in the Act. Whereas a medium-sized business is a productive economic business that stands alone, which is carried out by an individual or business entity that is not a subsidiary or branch company that is owned, controlled, or is a part, either directly or indirectly, from micro businesses, small businesses, or large businesses that meet the criteria for medium-sized businesses as referred to in Law. The criteria used to define MSMEs as listed in Article 6 of RI Law Number 20 Year 2008 are the value of net assets or the value of assets excluding land and buildings, places of business, or annual sales results. Micro businesses meet the criteria of having a net worth of at most fifty million rupiahs and annual sales of at most three hundred million rupiahs. Small businesses are business units that have a net worth of more than Rp 50 million to a maximum of five hundred million rupiahs and have annual sales results of more than three hundred million rupiahs to a maximum of two and a half billion rupiahs. While medium-sized businesses are companies with a net worth of more than five hundred million rupiahs to a maximum of ten billion rupiahs and have annual sales results of over two and a half billion rupiahs to a maximum of fifty billion rupiahs.

\subsection{Financial Technology}

According to Bank Indonesia (2017), financial technology is the use of technology in the financial system that produces new products, services, technology and / or business models and can have an impact on monetary stability, financial system stability, and / or efficiency, fluency, security, and payment system reliability. Financial technology or financial technology is categorized into several types, namely (1) Payment System, which also covers authorization, clearing, final settlement, and payment 
implementation, for example electronic money and mobile payments (2) Market Supporters, used to facilitate faster information delivery and cheaper related to financial products and / or services, for example providing comparative data on financial product or service information (3) Investment and Risk Management, for example online investment products and online insurance (4) Lending, Financing (financing or funding), and Capital raising, for example information technology based lending and borrowing services (Peer to Peer Lending) and financing or fundraising based on information technology (crowd-funding) (5) Other Financial Services, are not included in first to fourth categories. The laws and regulations governing financial technology in Indonesia, namely Bank Indonesia Regulation No.19 / 12 / PBI / 2017 Concerning Financial Technology Implementation.

\subsection{Information Technology Based Money Lending and Borrowing Services}

Information technology based lending and borrowing services according to the OJK (2016) is the organization of financial services to bring lenders together with loan recipients in the context of entering into loan agreements to borrow in rupiah directly through an electronic system using the internet network. In Indonesia, there are laws and regulations governing Peer to Peer (P2P) Lending, namely Regulation of the Financial Services Authority Number 77/POJK.01/2016 Concerning Information Technology Lending and Borrowing Services. In the process involved three parties, namely (1) Service Provider, which is an Indonesian legal entity that provides, manages, and operates Information TechnologyBased Money Lending and Borrowing Services (2) Loan Recipients, are persons and / or legal entities that have debts due to service agreements Information Technology-Based Money Lending and Borrowing, and (3) Lenders, i.e. persons, legal entities, and / or business entities that have receivables due to Information Technology-Based Lending and Borrowing Service agreements. According to Galloway (2009), providers of Peer to Peer (P2P) Lending services will match borrowers and lenders. The loan recipient will provide information on himself both personally and financially, then the lender will decide whether to contribute to the loan request or not. Each loan will be borne by several lenders, each of whom will contribute a portion of the loan until the loan is fully funded. After being fully funded, the loan will be returned based on its origin and the lender will get a proportion of the principal and interest payments until the loan is due.

According to Davis and Murphy (2016) the basic model of Peer to Peer (P2P) Lending is depicted in Fig. 1.

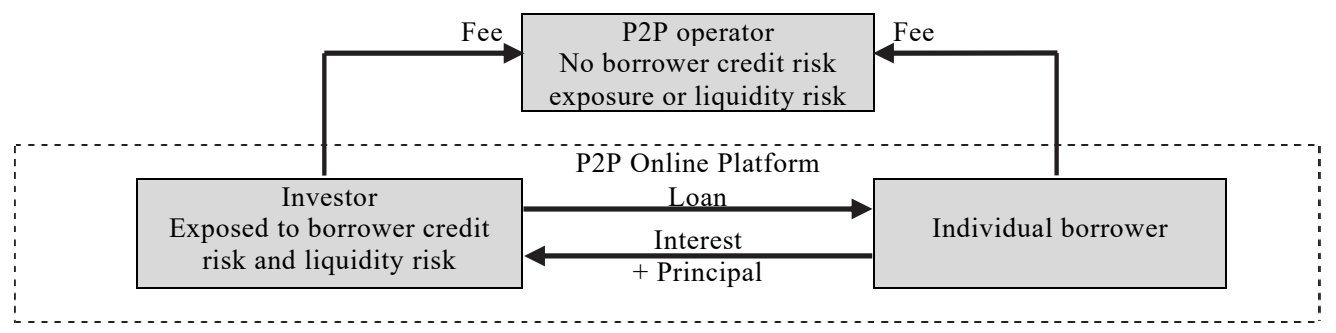

Fig. 1. Basic P2P Lending Model

The Peer to Peer (P2P) Lending Organizer will match borrowers and lenders (investors) through platforms rather than acting as traditional financial intermediaries. The organizer evaluates the credit of the borrower, and if the credit is considered appropriate, the loan request will be registered on the platform along with information related to the risk for the investor to borrow funds. Investors choose loan requests based on their individual risk appetite. Investors are either forced or strongly encouraged to invest in smaller denominations in several loans than are exposed to risk in one loan. After the loan is fully funded, the borrower's funds will be given. The organizer will monitor and manage the loan on behalf of the investor. Organizers do not invest their funds into loans in the ceiling so that they are not exposed to credit risk even though they are responsible for credit assessment, the main source of income is the cost of borrowing transactions.

\section{The proposed method}

Based on the background of the problem, this study aims to determine the role of financial technology for the development of capital and financing of MSMEs in the centers of entrepreneurship under the Regional National Crafts Council (Dekranasda) of Denpasar City through services, accessibility. There are two independent variables in this study, namely service and accessibility. Indicators in service are speed in service, friendly attitude is always shown in providing services, service accordingly, accuracy when providing services and the establishment of a comfortable atmosphere in service. The second independent variable is accessibility is the ease of MSMEs in getting access to the products offered. Indicators of accessibility are clear and complete information about financing and credit, the conditions provided are not burdensome, transactions are easy to do, disbursement of funding and credit funds are fast, and websites are easy to get. The population in this study is the 
members of the Denpaar City Dekranasda and the determination of the sample using a purposive sampling method, has a weaving craft business and has been fostered for at least 3 years. The method of data collection is done by questionnaire, documentation and interview. Data analysis methods in this research are instrument test, classic assumption test, and hypothesis test with SPSS program. The results of the study are said to be valid if there are similarities between the data collected and the data that actually occurs on the object under study. Validity test is used to determine the ability of instruments to measure what should be measured. The number of samples in this study were 30 respondent samples known r-count of 0.361 at the significance level $(\alpha)$ of 0.05 (Reinharz \& Davidman, 1992). If the obtained r-count is greater than the r-table determined, namely in this study amounting to 0.361 , the questionnaire is declared valid. The results of the study are reliable if there are similarities of data at different times. Reliability tests are used to measure the consistency of the questionnaire in measuring the same symptoms. The reliability test of 30 respondents using the Cronbach alpha technique, where if the reliability coefficient of the instrument is greater than 0.6 then it is declared reliable.

Data obtained from 30 respondents recorded as samples in this study, obtained description of descriptive statistical data of respondents as seen in Fig. 2. Fig. 2 shows the age of respondents is over 30 years, the dominant has been in business for more than 10 years. This business is dominated by women craftsmen, where 66.6 percent of craftsmen are women. As for the craftsmen of men better master the weaving design concepts that are made.

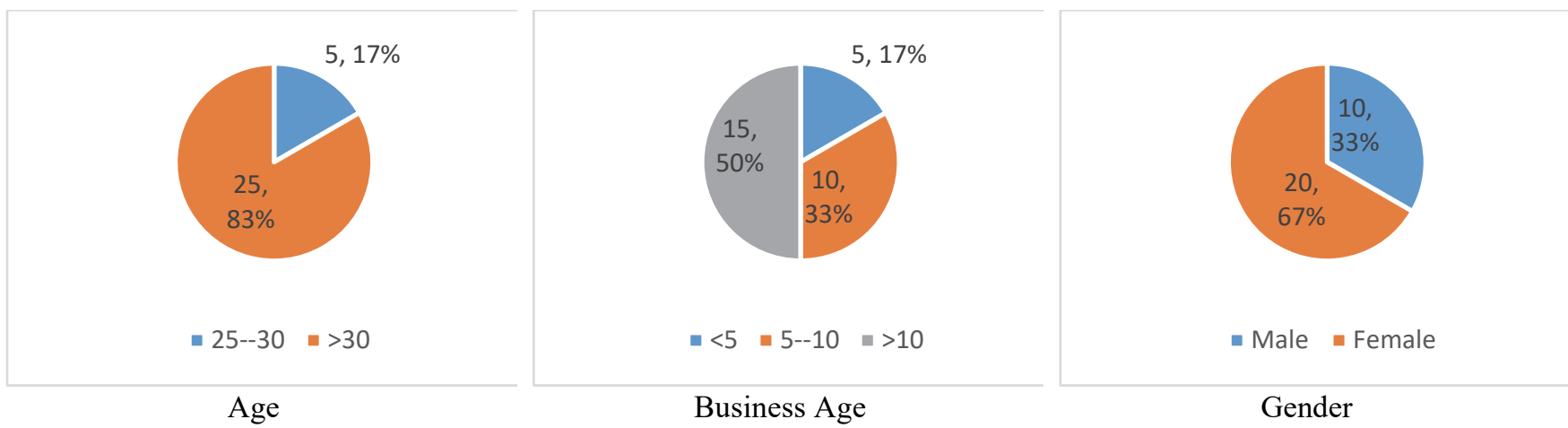

Fig. 2. Characteristics of Respondents

Source : Research Data

To see how the influence of fintech agent services and accessibility on MSME capital development, a multiple linear regression analysis was performed. The results of the multiple linear regression analysis presented in Table 1 show that fintech agent services and accessibility to fintech affect the development of MSME capital. Based on the results of the analysis show Hypotheses 1 and 2 were accepted at the 5\% significant level. This means that service and accessibility affect the development of MSME capital.

Table 1

Multiple Linear Regression Results

\begin{tabular}{llll}
\hline Model & $\beta$ & t statistics & Sig. \\
\hline (Constant) & 5.856 & 2.478 & 0.019 \\
Services & 0.374 & 3.839 & 0.000 \\
Accessibility & 0.479 & 4.266 & 0.000 \\
\hline & & F & Sig. \\
& & 15.321 & 0.009 \\
\hline Model Summary & R. square & 0.448 & \\
\hline
\end{tabular}

Source: Research data

The results show that the services provided by fintech companies influence the development of MSME capital. This shows that the MSMEs felt very helped by the services and products provided by the fintech companies and the facilities provided could help for the capital development of MSMEs. The results of the statistical analysis also show that accessibility variables had a significant effect on the capital development of MSME actors. The community is the perpetrators of MSMEs currently using technology in their daily lives. This millennium brings a huge development and impact on the world of digital technology. Fintech can make people not bother doing time-consuming activities, such as waiting in line at the bank for money transfers and others. Enough with a smartphone hand held the work can be completed in less than 5 minutes. Fintech is a computer 
program and other technology used to support or enable banking and financial services. Financial technology or digitalization has a strong impact on the financial services industry in providing financial services. The role of Financial Technology is developing so rapidly for the world economy today, banks are currently carrying out conventional operational activities, namely relying on activities through branch offices, which tend to be exclusive. However, banks must innovate in their business activities, one of which can be done is by collaborating with Fintech companies. Thus, by cooperating with Fintech companies, the products offered by banks will be accessible to all business people in all regions of Indonesia. Banking will be closer to business players (MSMEs). Meanwhile, the presence of a number of Fintech companies also contributed to the development of MSMEs. Not only is it limited to helping finance venture capital, Fintech's role has also expanded to various aspects such as digital payment services and financial arrangements.

\section{Conclusion and recommendation}

The purpose of this research was to look at the effect of fintech services and accessibility on MSME capital development. Based on the results of research in the field of the role of financial technology on MSME capital development shows that it has a positive effect on MSME capital development in the weaving industry in Denpasar City. Better access of MSMEs to financial technology will increase the capital development of MSMEs and accessibility plays a role in MSMEs capital development in Denpasar City. Services and assistance in the selection of products offered by companies engaged in financial technology have had a positive impact so that the services provided play an essential role for the development of MSMEs capital in Denpasar. The role of service in the form of assistance is very important for MSMEs because it will facilitate the development of capital owned by MSMEs. To further enhance the role of financial technology in the development of MSME capital in Denpasar, it should provide more services to MSME entrepreneurs, which would attract MSME entrepreneurs to conduct fintech transactions. The better the services provided; the better customer become loyal. Aside from service, fintech companies should also be able to increase assistance to MSMEs. Assistance is carried out so that the development of MSME capital is improved and can be managed well. Assistance can be in the form of guidance related to loans and capital as well as assistance during the process of financing and credit and provide clear information to customers. The UMKM, with advances in technology, should be able to take advantage of the ease of access or accessibility of facilities provided by fintech companies and it can increase company capital.

\section{Acknowledgement}

The authors would like to thank the anonymous referees for constructive comments on earlier version of this paper.

\section{References}

Davis, K. T., \& Murphy, J. (2016). Peer to Peer lending: structures, risks and regulation. Kevin Davis and Jacob Murphy "Peer to Peer Lending: Structures, Risks and Regulation" JASSA: The Finsia Journal of Applied Finance, 2016, 3-37.

Irmawati, S., Damelia, D., \& Puspita, D. W. (2013). Model Inklusi Keuangan Pada UMKM Berbasis Pedesaan. JEJAK: Jurnal Ekonomi dan Kebijakan, 6(2).

Khouroh, U., Sudiro, A., Rahayu, M., \& Indrawati, N. (2020). The mediating effect of entrepreneurial marketing in the relationship between environmental turbulence and dynamic capability with sustainable competitive advantage: An empirical study in Indonesian MSMEs. Management Science Letters, 10(3), 709-720.

Kustina, K. T., Dewi, I. G. A. A. O., Prena, G. D., \& Utari, I. G. A. D. (2018). MSMEs credit distribution and non-performing loan towards banking companies profit in Indonesia. International Journal of Social Sciences and Humanities, 2(1), 10-23.

Lussak, A., Abdurachman, E., Gautama, I., \& Setiowati, R. (2020). The influence of financial performance and innovation of services and products on the survival of small businesses in food and beverage in the Jakarta city with mediation of operational improvement. Management Science Letters, 10(2), 463-468.

Maier, F., Meyer, M., \& Steinbereithner, M. (2016). Nonprofit organizations becoming business-like: A systematic review. Nonprofit and Voluntary Sector Quarterly, 45(1), 64-86.

Ministry of Cooperatives and Small and Medium Enterprises (2017). https://www.pegadaian.co.id/produk/krasida

Reinharz, S., \& Davidman, L. (1992). Feminist Methods in Social Research. Oxford University Press.

Sihotang, J., Puspokusumo, R. A. A. W., Sun, Y., \& Munandar, D. (2020). Core competencies of women entrepreneur in building superior online business performance in Indonesia. Management Science Letters, 10(7), 1607-1612.

Yacob, S., Erida, E., Machpuddin, A., \& Alamsyah, D. (2021). A model for the business performance of micro, small and medium enterprises: Perspective of social commerce and the uniqueness of resource capability in Indonesia. Management Science Letters, 11(1), 101-110. 


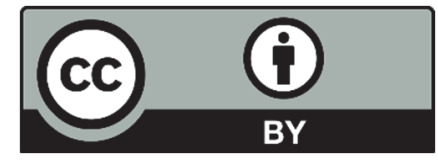

(C) 2020 by the authors; licensee Growing Science, Canada. This is an open access article distributed under the terms and conditions of the Creative Commons Attribution (CC-BY) license (http://creativecommons.org/licenses/by/4.0/). 